\title{
Araucaria angustifolia grafting: techniques, environments and origin of propagation material
}

\author{
Injertación de Araucaria angustifolia: técnica, ambientes y fuente de material de propagación \\ Ivar Wendling a , Carlos A Stuepp ${ }^{\text {b* }}$, Katia C Zuffellato-Ribas ${ }^{c}$ \\ ${ }^{a}$ Embrapa, Centro Nacional de Pesquisa de Florestas, Colombo-PR, Brazil. \\ *Correspondence: ${ }^{\mathrm{b}}$ Universidade Federal do Paraná, Departamento de Fitotecnia e Fitossanitarismo, \\ Caixa postal 19061, Rua dos Funcionários 1540, Curitiba-PR, Brasil, tel/fax.: +554133505601, carlos.stuepp@ufpr.br \\ ${ }^{\mathrm{c}}$ Universidade Federal do Paraná, Departamento de Botânica, Curitiba-PR, Brazil.
}

\begin{abstract}
SUMMARY
Araucaria angustifolia (araucaria) is a remarkable species in the Mixed Ombrophilous Forest. The low germination of the stored seeds and its long reproductive cycle make grafting a good alternative for propagation, making possible to obtain genetically superior trees with early fruiting. However, araucaria grafting is still fraught with technical problems, culminating in low graft survival. With the objective to define and be able to explain the best methodology for the grafting of araucaria, we conducted studies based on five experiments evaluating the effects of: (I) environment and sex on graft survival; (II) methods of grafting and budding with shoots from stumps of stock plants; (III) techniques, indoor (nursery) and outdoor (directly in the field) grafting; (IV) budding with buds from different origins; and (V) chip budding with shoots from pruned apices of two ages stock plants. Graft survival was assessed throughout the experiments and the graft-union at the end. The use of controlled environments for grafting was favorable, especially in the glasshouse $(64.1 \%$ survival). Scions from female plants $(55.5 \%$ survival) showed higher suitability for grafting. Chip budding with shoots from pruned apices of 25 and 35-year-old stock plants showed survival of $87.5 \%$ and $85.0 \%$, respectively. It is a technology that has unlimited potential for araucaria grafting, which may significantly contribute to its sustainable use.
\end{abstract}

Key words: budding, Brazilian pine, clonal propagation, seed orchard, cleft graft.

\section{RESUMEN}

Araucaria angustifolia (araucaria) es una especie que se destaca en el bosque de araucaria. La baja germinación de las semillas almacena-das y su ciclo reproductivo largo hace que la injertación se presente como una alternativa para la producción de plantas seleccionadas, genéticamente superiores y con mayor precocidad para fructificación. Sin embargo, la injertación en araucaria aún presenta problemas técnicos, culminando con una baja supervivencia de los injertos. Con el objetivo de definir y explicar el mejor método para la injertación de araucaria, se llevaron a cabo estudios basados en cinco experimentos que evaluaron el efecto de: (I) los ambientes y el sexo en la supervivencia del injerto; (II) métodos de púa en hendidura y de yema con brotes de cepa; (III) injertación directamente en campo y vivero; (IV) injerto de yemas de diferentes orígenes; (V) injerto de yemas de brotes de ápices de árboles adultos podados con dos edades. Fueron evaluadas la supervivencia de los injertos durante los experimentos y el prendimiento de los injertos al final. La utilización de ambientes protegidos para la realización de la injertación fue favorable, destacándose el invernadero de vidrio $(64,1 \%$ de prendimiento). Yemas provenientes de plantas matrices femeninas $(55,5 \%)$ mostraron mayor aptitud para la injertación. El injerto de yema en placa de brotes de ápices de árboles adultos podados, 25 y 35 años, presentó resultados de $87,5 \%$ y $85,0 \%$, respectivamente. Es una tecnología que tiene gran potencial para el uso de araucaria, contribuyendo de manera significativa a su uso sostenible.

Palabras clave: injerto por yema, pino brasileño, propagación clonal, huerto clonal, injerto de hendidura.

\section{INTRODUCTION}

Araucaraia angustifolia (Bertol.) Kuntze (Araucariaceae), popularly known as araucaria or Brazilian pine, is the only species of its genus naturally occurring in Brazil (Kuhn and Mariath 2014). The species occurs mainly in the southern region, and can also be found in Paraguay and Argentina (Carvalho 2003), where it is widely used in the furniture industry (Gonçalves et al. 2014). These characte- ristics and the high added value of its wood (Delucis et al. 2013) were responsible for generating enormous exploitation of the species in the late nineteenth century (Danner et al. 2012). The species is also attractive for its seeds, popularly called Brazilian pine nuts, considered an excellent source of starch, low calorific fibers and magnesium, plus its low glycemic index (Cordenunsi et al. 2004).

Similarly to most conifers, araucaria is propagated by seeds. However, its short-lived seeds, combined with the 
disadvantages associated with this method of propagation such as indefiniteness of sex and high genetic variability in formed plants (Hartmann et al. 2011, Dias et al. 2012), make improving vegetative propagation techniques necessary. Among these, grafting has emerged as an excellent option to obtain plants with features of interest (i.e. gender and specific genetic qualities of the parent trees) and has been refined over years for araucaria (Gurgel and GurgelFilho 1967, Kageyama and Ferreira 1975, Wendling 2011, Zanette et al. 2011).

The efficiency of grafting depends, among other factors, upon the rootstocks capacity to adapt to different soils and climes, as well as good initial performance in different cultivation conditions (Reis et al. 2010). Therefore, environments with higher control of temperature and humidity, such as greenhouses, have been used for the application of the technique, providing advantages in the production of these plants, especially reducing the time required for grafted plant formation (Reis et al. 2010). Grafting has been widely used in commercial horticulture and can bring enormous benefits to establishing technically superior seed orchards compared with conventional seedling production systems, including the potential for using resistant or tolerant rootstocks and more productive grafts (Yin et al. 2012). A major benefit is the growth reduction of the progeny plant, giving up to $50 \%$ reduction in size compared to plants propagated by other methods (Prassinos et al. 2009). Grafting has been applied in forestry mainly for creating seed orchards, aiming for early fruits and seeds production (Dias et al. 2015).

For araucaria, grafting was initially studied (Kageyama and Ferreira 1975) with the use of four methods: cleft gra$\mathrm{ft}$, side-stub graft, whip graft and chip budding. The chip budding is also known as patch grafting (Nikles 1961). However, it did not become a technique with applications on a commercial scale, mainly because of difficulties in obtaining orthotropic branches with vertical growth and due to the large diameter of branches creating incompatibility between the thickness of rootstocks and of grafts. On the other hand, grafting of plagiotropic branches from mature trees on young rootstocks is feasible for araucaria (Zanette et al. 2011).

Likewise, Zanette et al. (2011) concluded that bark patch grafting is technically feasible in production of araucaria plants; however, survival rates did not exceed $50 \%$. Wendling (2011) cites the cleft graft technique and chip budding (or patch grafting) as the best for araucaria.

Here, we present the results of an investigation designed to reveal the influence of several factors toward improving araucaria grafting for plants production. We hypothesized that the management of grafted plants, as well as the selection of different propagation materials for use as graft, results in different percentages of survival of grafts. Through five experiments, we compared different indoor propagation environments, sex of the stock plants, management techniques for rootstock, origin of grafts and rootstocks, age and growth habit of the stock plants and grafting techniques, in order to define and be able to explain the best methodology for the grafting of araucaria.

\section{METHODS}

The experiment was conducted from August 2010 to September 2014 in the Laboratory of Forest Species Propagation, belonging to Embrapa Forestry, in the municipality of Colombo-PR, Brazil $\left(25^{\circ} 20^{\prime} \mathrm{S}\right.$ and $49^{\circ} 14^{\prime} \mathrm{W}, 950$ $\mathrm{m})$. According to the Köppen classification, the climate in the region is temperate, type $\mathrm{Cfb}$, with temperatures during the coldest month between -3 and $18{ }^{\circ} \mathrm{C}$, always humid with evenly distributed rainfall throughout the year and temperatures during the hottest month lower than $22{ }^{\circ} \mathrm{C}$. The materials used for grafting in all experiments were: pruning shears to make cuts in the rootstock, pocket knife to make the incision in the rootstock, and plastic tape to secure the graft to weld them. Five experiments were assembled, each consisting of an individual analysis of grafting methods and techniques.

All data were subjected to the Bartlett test $(P<0.05)$, to check homogeneity of variance; afterwards, the analysis of variance (ANOVA) $(P<0.01$ and $P<0.05)$, proceeding means comparison by Tukey test $(P<0.01$ and $P<0.05)$.

Experiment I - Effect of different environments and sex on graft survival. The rootstocks were produced from seeds in plastic bags measuring $35 \mathrm{~cm} \times 14.5 \mathrm{~cm}$, and at the time of grafting measured $40 \mathrm{~cm}$ high and $10 \mathrm{~mm}$ mean diameter. The grafts came from branches with growth habit named "tending to orthotropic" (Wendling 2011), found in a canopy of mature araucaria trees, collected and grafted in August 2010 by cleft graft (Wendling 2011). After grafting, the plants were placed in two environments: greenhouse and glasshouse, with different irrigation frequencies, temperature and humidity (table 1). The survival of grafts was assessed at 60, 90, 120 and 150 days in different environments according the sex of the parental plants.

Grafts placed in glasshouses were surrounded by a clear plastic bag for wet chamber formation to reduce moisture loss. The grafts maintained in the glasshouse also were packaged with Kraft paper around the plastic bag for protection against excessive light. The plastic tape was kept for three months, or less if there was thickening of the stems. Plastic bags were opened when grafts started sprouting, then removed 10 days later along with paper packaging. Because of their lower incidence of light and higher humidity, grafts stored in greenhouses received no protection. A completely randomized design with two replications of seven grafts was used.

Experiment II - Grafting methods using coppice shoots. The rootstocks were the same as in Experiment I. The grafts were obtained from coppice shoots of mature trees cut in July 2009. The grafting was carried out in November 
Table 1. Averages temperature and humidity on different environments utilized for Araucaria angustifolia grafting experiments.

Temperatura y humedad media en diferentes ambientes utilizados en el injerto de $A$. angustifolia.

\begin{tabular}{cccc}
\hline Environment & $\begin{array}{c}\text { Temperature* } \\
\left({ }^{\circ} \mathrm{C}\right)\end{array}$ & $\begin{array}{c}\text { Humidity* } \\
(\%)\end{array}$ & Irrigation \\
\hline Greenhouse & $20 \pm 10$ & $>80$ & $\begin{array}{c}\text { Intermittent } \\
\text { nebulization }\end{array}$ \\
Glasshouse & $20 \pm 18$ & $20-90$ & $\begin{array}{c}\text { Sprinkling (1 min, } \\
3 \text { times per day) }\end{array}$ \\
\hline
\end{tabular}

* There was only temperature and humidity control in the greenhouse.

2011, evaluating the cleft graft, whip-and-tongue graft, whip graft and chip budding (Hartmann et al. 2011).

After grafting, the grafts were placed in a glasshouse, with irrigation, humidity and temperature conditions similar to those used in Experiment I (table 1). The chip budding grafts were only tied with plastic tape, which was removed after 42 days. Survival was assessed at 45, 75, 100 and 130 days in the glasshouse. A completely randomized design with four treatments, five replicates of five plants per experimental unit was used.

Experiment III - Techniques, indoor and outdoor grafting. Rootstocks were seedlings established in a nursery (as described in Experiment I) and directly in the field (trial witness), with heights of $80-100 \mathrm{~cm}$ and a mean diameter of $12 \mathrm{~mm}$. The grafts were obtained from shoots of 3.5-year-old grafted plants that showed growth habit "tending to orthotropic" (Wendling 2011). The mother tree had its scion originated from "tending to orthotropic" (Wendling 2011) shoots issued in primary branches of a mature, 30-year-old tree. The experiment began in April 2011, with eight treatments related to grafting technique, methods of rootstock pruning and environment for grafts maintenance (table 2). The techniques were budding flute and chip budding (Hartmann et al. 2011).

After grafting, indoor grafts were placed in a shade house for 30 days, with irrigation (Sprinkling $1 \mathrm{~min}$, 5 times per day), humidity ( $24-95 \%)$ and temperature conditions $\left(18 \pm 15{ }^{\circ} \mathrm{C}\right)$. Later, they were transferred to a full sunlight area with irrigation system by spraying for 20 minutes, three times a day for a period of 150 days. The grafts were tied only with plastic tape which was removed after 42 days. Survival was evaluated at 30 days in the shade house and at 120 and 180 days in full sunlight. Outdoor grafts were evaluated at the same time as indoor grafts. A completely randomized design with five replicates of ten plants indoors and five plants outdoors was used.
Table 2. Treatment descriptions, grafting methods, rootstock management and grafting environment for Araucaria angustifolia on Experiment III.

Descripciones de los tratamientos, métodos de injerto, gestión de los portainjertos y ambientes de injertación de $A$. angustifolia en Experimento III.

\begin{tabular}{cccc}
\hline Treatment & $\begin{array}{c}\text { Budding } \\
\text { technique }\end{array}$ & $\begin{array}{c}\text { Rootstock } \\
\text { pruning }\end{array}$ & Environment \\
\hline T1 & Flute & Close to graft & Indoor \\
T2 & Flute & Only apex & Indoor \\
T3 & Flute & Without & Indoor \\
T4 & Chip & Close to graft & Indoor \\
T5 & Chip & Without & Indoor \\
T6 & Chip & Only apex & Indoor \\
T7 & Flute & Only apex & Outdoor \\
T8 & Chip & Only apex & Outdoor \\
\hline
\end{tabular}

Experiment IV-Chip budding with buds and rootstocks of different origins. Rootstocks were seedlings with $50-60 \mathrm{~cm}$ in height and a diameter of approximately $12 \mathrm{~mm}$, grown in glasshouse conditions (table 1). The experiment was carried out in February 2011, with four scion origins and rootstocks originating from two mother plants (table 3). The scions originated from three 30-year-old female mother plants (figure 1A).

After grafting, plants were placed in a shade house with sprinkler irrigation (Experiment III) for 30 days. Subsequently, they were relocated to a full sunlight area with irrigation by sprinkler system for 20 minutes, three times a day for 180 days. Survival at 30 days in the shade house and at 60,90,120 and 210 days at the full sunlight area was evaluated. A completely randomized design with four scion origins and two rootstocks, four replicates and five plants per plot was used.

Experiment V - Chip budding with shoots from pruned apices of two ages stock plants. Details of apical pruning and grafting procedures are described in Wendling (2015). Briefly, rootstocks were seedlings (seeds from two mother plants) with $80-100 \mathrm{~cm}$ in height and a diameter of approximately $12 \mathrm{~mm}$, grown outdoors (field conditions), since April 2013. The experiment was established in September 2014 , directly in the field, with buds from pruned apices of two ages stock plants (35-year-old mother plants and 25-year-old mother plants), collected 15 months after apex pruning (figure 1B).

Survival at 30,60, 90, 120 and 150 days was evaluated. A completely randomized design with two mother tree ages, eight replicates and ten plants per plot was used. 
Table 3. Origin of rootstocks and grafts for budding in Araucaria angustifolia on Experiment IV.

Origen de los portainjertos y los injertos en A. angustifolia en el Experimento IV.

\begin{tabular}{cccc}
\hline Treatment & Mother tree & Scions origin & Rootstock \\
\hline 1 & Tree 1 & 3.5-year-old grafted plant originating from primary canopy shoots & 1 \\
2 & (figure 1A - Scion a) & 1 \\
3 & Tree 2 & "Tending to orthotropic" shoots (Figure 1A - Scion b) & 1 \\
4 & "Tending to orthotropic" shoots (figure 1A - Scion b) & 1 \\
5 & Same as treatment 1 & "Tending to orthotropic" shoots (figure 1A - Scion b) & 1 \\
6 & Same as treatment 2 & Same as treatment 1 & 2 \\
7 & Same as treatment 3 & Same as treatment 2 & 2 \\
8 & Same as treatment 4 & Same as treatment 3 & 2 \\
\hline
\end{tabular}

A

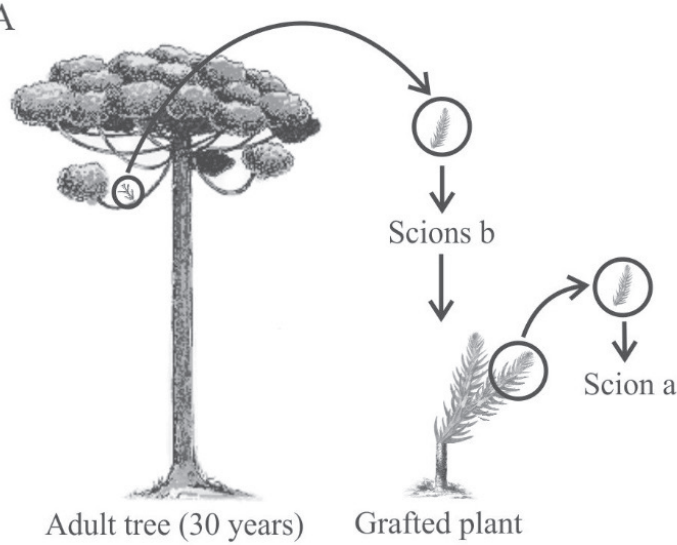

B

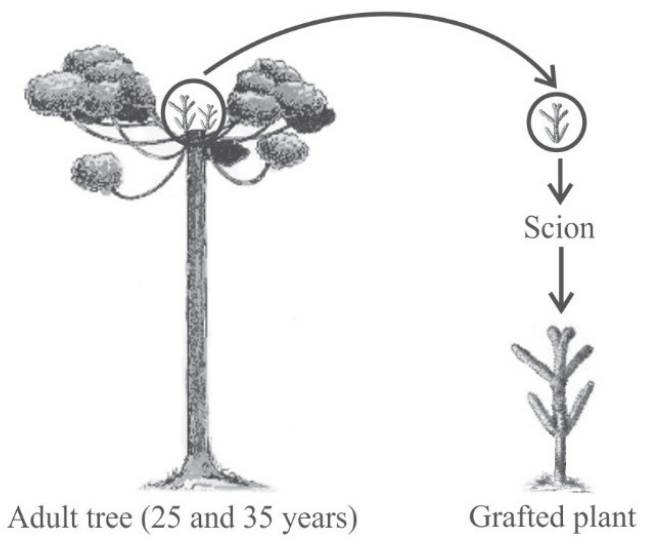

Figure 1. Origin of scions used for Araucaria angustifolia grafting. A: Experiment IV (Scions “a” and "b”) and B: Experiment V. Origen de los propágulos utilizados para injertación en A. angustifolia. A: Experimento IV (propágulos “a” y “b”) y B: Experimento V.

\section{RESULTS}

In Experiment I, no significant differences on grafts survival between the greenhouse and the glasshouse were observed at 60, 90, 120 and 150 days after grafting (figure 2A). Regardless of graft maintenance environment, female grafted plants proved to be superior in survival than male ones in all evaluation periods (figure 2B).

In Experiment II, plants grafted with budding technique proved to be significantly superior to other techniques at 45 days after grafting. However, at ages 75, 100 and 130 days after grafting all techniques presented similar results (figure 3).

In Experiment III, flute budding with apex pruning and without pruning showed higher survival compared to other techniques at 120 and 180 days after grafting (figure 4).

In Experiment IV, statistical differences were found between the two rootstock origins at 30,60 and 90 days after grafting, however, survival at 210 days after grafting was low, regardless of rootstock and grafts origin (figure 5).
In Experiment V, the use of the chip budding technique with shoots from pruned apices of adult stock plants (figure 1B) showed excellent survival results at 150 days after grafting (figure 6), regardless of mother plants age which originated the buds.

\section{DISCUSSION}

The absence of significant variations in grafting survival between the greenhouse and the glasshouse (figure 2A) is probably related to appropriate conditions for the implementation of the technique. The need for appropriate environments for proper establishment of woody species grafts has been highlighted in literature, especially during the first 30 days after grafting (Reis et al. 2010), when higher difficulty of interaction between rootstock and scion may directly affect vascular reconnection (Yin et al. 2012).

Even without improvement in survival and establishment percentage, the allocation of recently made grafts in 


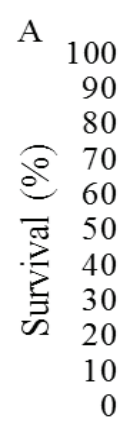

60

90

Period after grafting (days)

$\rightarrow$ Greenhouse $\rightarrow-$ Glasshouse

$\mathrm{B}$

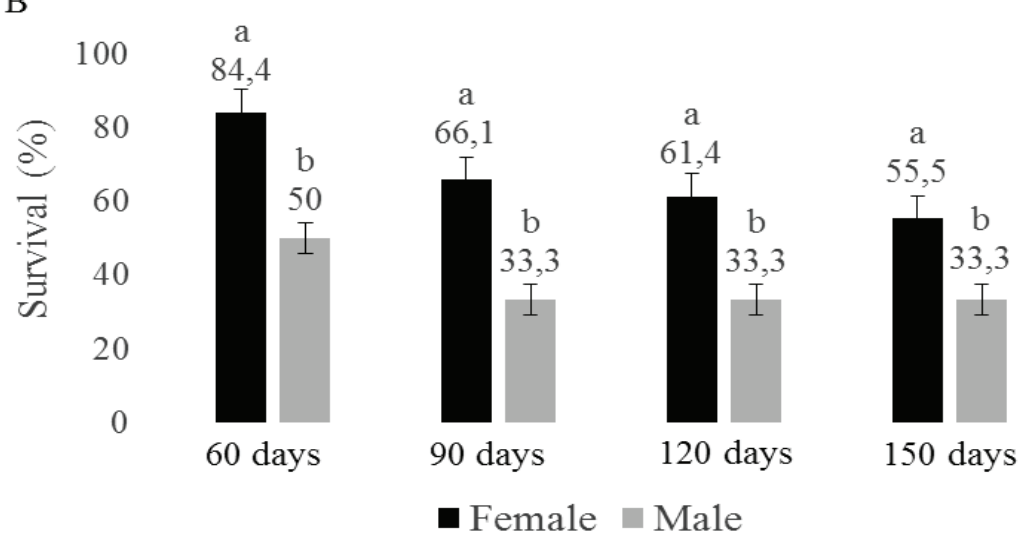

Figure 2. Araucaria angustifolia graft survival at 60,90, 120 and 150 days after grafting as a function of grafts maintenance environment (A) and gender (B) (Experiment I). Means followed by the same letter do not differ by Tukey test $(P \leq 0.05)$. Error bars indicate the standard error of the mean.

Supervivencia de injertos de A. angustifolia a los 60, 90, 120 y 150 días después del injerto en función del medio ambiente de conducción (A) y el género (B) (Experimento I). Promedios seguidos por la misma letra no difieren entre si según Tukey $(P \leq 0,05)$. Las barras indican el error estándar de la media.

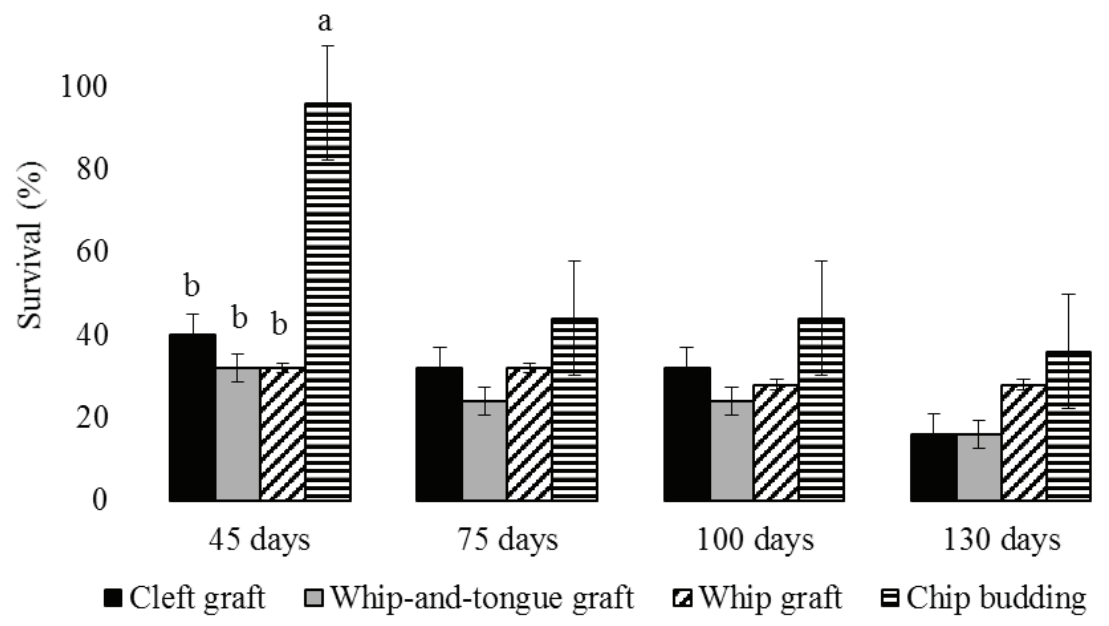

Figure 3. Araucaria angustifolia grafts survival at 45, 75, 100 and 130 days after grafting as a function of grafting technique (Cleft graft; Whip-and-tongue graft; Whip graft and Chip budding). Means followed by the same letter do not differ by Tukey test $(P \leq 0.05)$. Error bars indicate the standard error of the mean.

Supervivencia de injertos de A. angustifolia a los 45, 75, 100 y 130 días después del injerto en función de la técnica de injerto (Injerto en púa en hendidura simple; Injerto en púa inglés o de lengüeta; Injerto en púa inglés simple y Injerto de yema). Promedios seguidos por la misma letra no difieren entre si según Tukey $(P \leq 0,05)$. Las barras indican el error estándar de la media. 


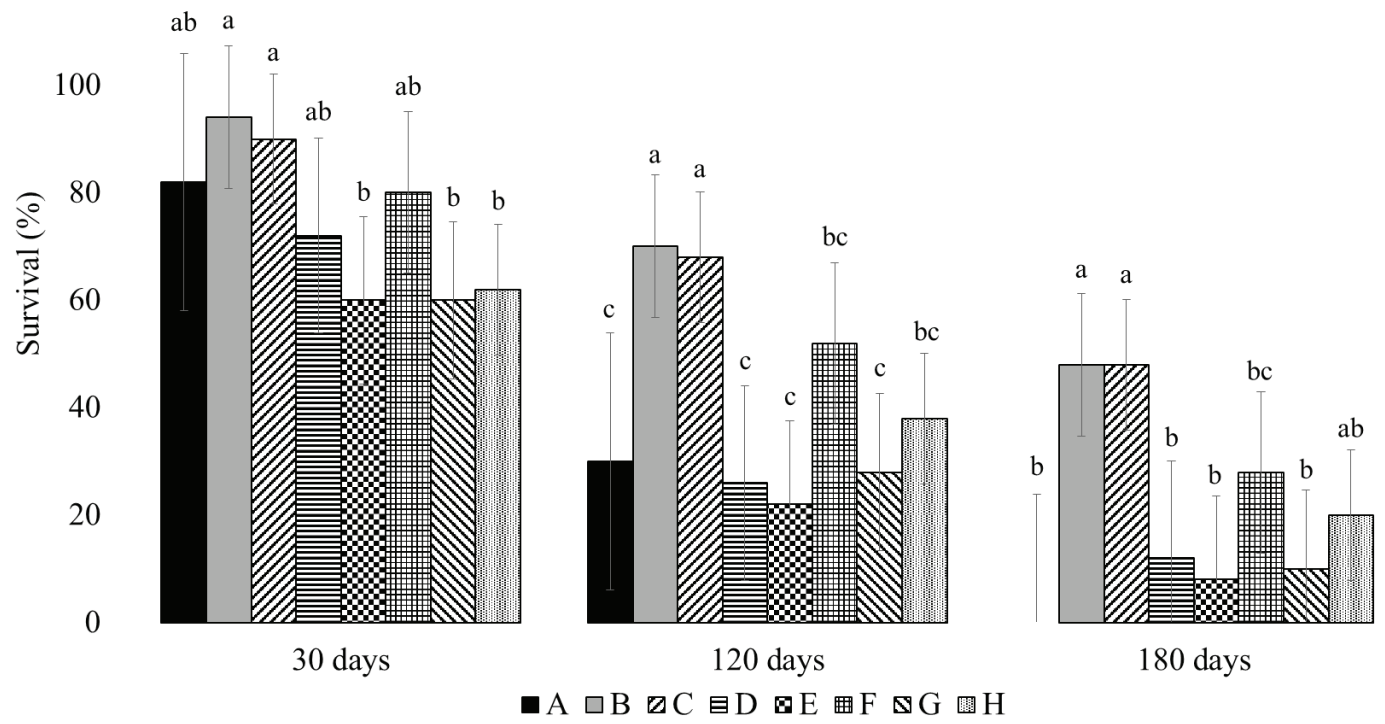

Figure 4. Araucaria angustifolia grafts survival at 30,120 and 180 days after grafting as a function of grafting technique, type of rootstock pruning and grafting environment (Experiment III - table 2). A: Flute budding, close pruning (indoor); B: Flute budding, apex pruning (indoor); C: Flute budding, without pruning (indoor); D: Chip budding, close pruning (indoor); E: Chip budding, without pruning (indoor); F: Chip budding, apex pruning (indoor); G: Flute budding, apex pruning (outdoor); H: Chip budding, apex pruning (outdoor). Means followed by the same letter do not differ by Tukey test $(P \leq 0.05)$. Error bars indicate the standard error of the mean.

Supervivencia de injertos de $A$. angustifolia a los 30, 120 y 180 días después del injerto en función de la técnica de injerto, tipo de poda del portainjerto y el medio ambiente de injertación (Experimento III - cuadro 2). A: Injerto de canutillo, con poda cerca del injerto (protegido); B: Injerto de canutillo, con poda del ápice (protegido); C: Injerto de canutillo, sin poda (protegido); D: Injerto de yema, con poda cerca del injerto (protegido); E: Injerto de yema, sin poda (protegido); F: Injerto de yema, con poda del ápice (protegido); G: Injerto de canutillo, con poda del ápice (aire libre); H: Injerto de yema, con poda del ápice (aire libre). Promedios seguidos por la misma letra no difieren entre si según Tukey $(P \leq 0,05)$. Las barras indican el error estándar de la media.

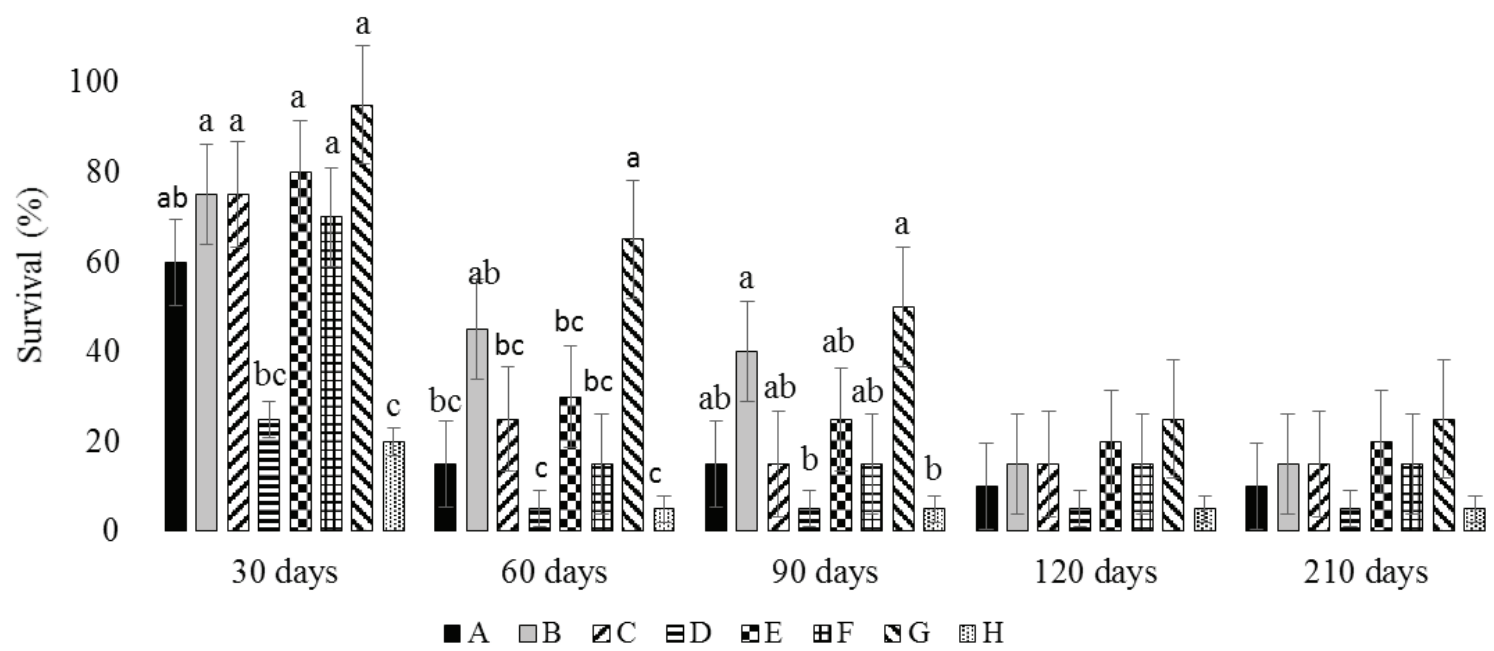

Figure 5. Araucaria angustifolia grafts survival at 30,60, 90, 120 and 210 days after grafting as a function of rootstock and scion origin (Experiment IV - table 3). A: Rootstock 1 (Scion a); B: Rootstock 1 (Scion b); C: Rootstock 1 (Scion b); D: Rootstock 1 (Scion b); E: Rootstock 2 (Scion a); F: Rootstock 2 (Scion b); G: Rootstock 2 (Scion b); H: Rootstock 2 (Scion b). Means followed by the same letter do not differ by Tukey test $(P \leq 0.05)$. Error bars indicate the standard error of the mean.

Supervivencia de injertos de $A$. angustifolia a los 30,60, 90,120 y 210 días después del injerto en función de portainjerto y origen de yemas (Experimento IV - cuadro 3). A: Portainjerto 1 (Propágulo a); B: Portainjerto 1 (Propágulo b); C: Portainjerto 1 (Propágulo b); D: Portainjerto 1 (Propágulo b); E: Portainjerto 2 (Propágulo a); F: Portainjerto 2 (Propágulo b); G: 2 Portainjerto (Propágulo b); H: Portainjerto 2 (Propágulo b). Promedios seguidos por la misma letra no difieren entre si según Tukey $(P \leq 0,05)$. Las barras indican el error estándar de la media. 


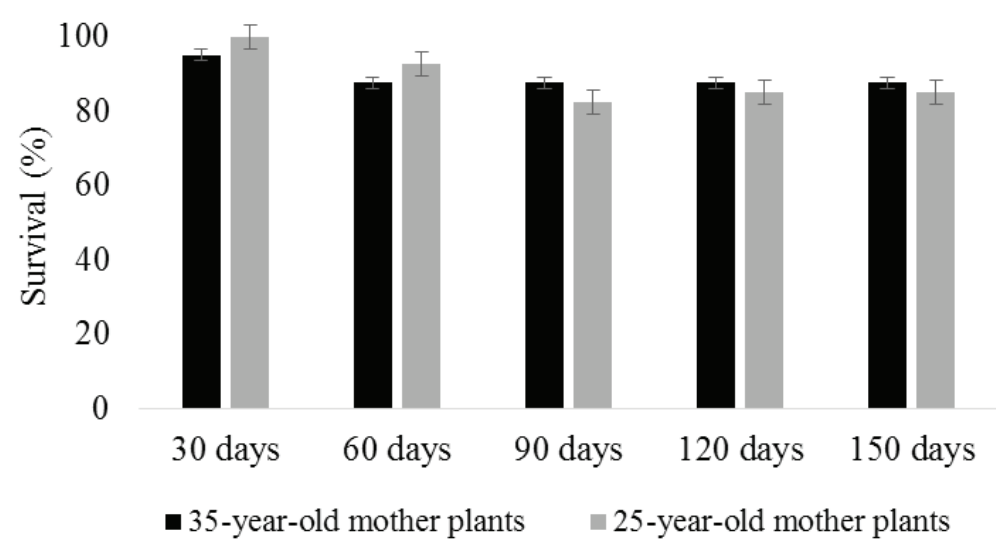

Figure 6. Araucaria angustifolia graft survival at 30,60, 90, 120 and 150 days after grafting for the chip budding technique with shoots from pruned apices, depending on the age of the mother plants used as graft (Experiment V). Error bars indicate the standard error of the mean.

Supervivencia de injertos de A. angustifolia a los 30, 60, 90, 120 y 150 días después del injerto para técnica de yema en placa de brotes de ápices de árboles adultos podados, en función de la edad de las matrices utilizadas como injerto (Experimento V). Las barras indican el error estándar de la media.

a greenhouse can generate benefits associated with better control over environmental variables such as light, humidity and temperature. Thus, it is not necessary to form a humid chamber with a plastic bag over the scion to reduce moisture loss or to protect against excessive light with Kraft paper. Other studies show that the use of protected environments such as greenhouses has expanded the success of grafting, increasing survival, streamlining the process of union and, consequently, reducing the time for production (Reis et al. 2010).

The higher survival of female grafts (figure 2B) can be attributed to ecological and morphological differences between the sexes in dioecious species, which can directly influence the regenerative capacity of grafts (Han et al. 2013) and rooting of cuttings. It is assumed that females allocate more resources for reproduction than males do, generating an asymmetry between sexes. This is a result of differences in distribution of resources for growth and reproduction of these individuals, also including differences in photosynthetic activity and transpiration rate (Dawson and Bliss 1993, Dawson and Ehleringer 1993), making female gender most sensitive to environmental conditions (Dawson et al. 2004, Nanami et al. 2005, Iszkuło et al. 2008, Rozas et al. 2009).

Grafting has been studied for araucaria (Gurgel and Gurgel-Filho 1967, Kageyama and Ferreira 1975, Wendling 2011, Zanette et al. 2011), resulting in male flowering plants at four years (Wendling, 2011) and female at 6.5 years (Wendling 2015) after grafting, with cleft grafts from "tending to orthotropic growth" shoots. However, the technique has not been employed in large scale probably because of the impossibility of using adult tree apical shoots due to their large diameters, as well as due to a number of technical difficulties related to the survival and welding quality of the graft union with the rootstock when using grafts from adult trees (Wendling 2011).

The success of whip-and-tongue grafts has been reported for several woody species, including Cydonia oblonga Mill. (Pio et al. 2008) and Allanblackia floribunda Oliv. (Asaah et al. 2011). In temperate fruit trees, this method has a high rate of success, generally above $95 \%$ (Leite et al. 2013). However, for araucaria this technique was not feasible, a fact expressed by the low graft survival observed in the present study (figure 3), as well as the results described in Gurgel and Gurgel-Filho (1967). However, the advantage of whip-and-tongue grafts to have a higher vascular cambium surface contact between scion and rootstock (Ofori et al. 2008), and the low survival rates of cleft grafts (figure 3 ) can justify the need for further studies with $A$. angustifolia.

The sharp fall of survival rates for budding between 45 and 75 days after grafting (figure 3) may be related to the withdrawal of plastic tape after 42 days, which had not yet interfered in the first assessment at 45 days after grafting. These results can be explained by poor welding between scion and rootstock at the time of removal of the plastic tape, leaving the contact surface exposed to oxidation and moisture infiltration (Yin et al. 2012), indicating the need for their maintenance for longer periods of time. Another hypothesis that needs to be further investigated and may explain this sharp drop in survival is the excess of heat (in December) caused by directly incident sunlight on the buds after tape removal. Zanette et al. (2011) obtained $65 \%$ araucaria graft survival in autumn as the best result after removing the plastic tape at 80 days after grafting, but only $20 \%, 5 \%$ and $0 \%$ for spring, winter, and summer grafting, respectively, indicating the necessity of further studies to clarify these effects. 
The whip graft and budding techniques resulted in a higher survival rate at 130 days after grafting (figure 3), recommending its use for araucaria grafting. However, budding gives a better performance when using orthotropic branches available in small quantities, i.e. a larger amount of scions may be obtained from the same shoot as compared to cleft grafting. Budding also features more easily in its execution, with good contact area between graft and rootstock, thereby facilitating their union and survival (Martínez-Ballesta et al. 2010, Hartmann et al. 2011, Yin et al. 2012).

In Experiment III, indoor (nursery) conditions were important in maintaining graft survival, especially in the first 30 days after grafting when kept in a shade house, resulting in higher survival (figure 4). When comparing indoor and outdoor environments and flute and chip techniques, the indoor flute was superior at 180 days after grafting (data not shown). However, outdoor grafting can be a viable alternative for araucaria, especially when considering shoots vigor (data not shown). Grafting in protected environments, like greenhouses, favors graft quality since it provides better temperature and humidity conditions, maintaining cell turgor, avoiding stress by dehydration of the material and generating a consequent precocity in graft establishment (Lee et al. 2010).

Several studies have linked low levels of graft survival to some sort of incompatibility between rootstock and scion (Munjunga et al. 2013, Han et al. 2013). Improper grafting technique is one of the limiting factors of its success, especially by poor contact in the cambium region, mechanical damage during bus withdrawal and disuniform cuts (Hartmann et al. 2011). The use of techniques, such as the flute method, that require a less skilled grafter, facilitating engagement between scion and rootstock to increase the contact surface, tend to have better rates of survival, resulting in superior success of this technique compared with others.

The low final survival of grafts in Experiment IV (figure 5) compared with Experiment V (figure 6) can be attributed to differences in physiological age and growth habit of the used shoots (Figure 1A and figure 1B, respectively). Physiological ageing refers to the physiological vigor of a plant, relative to the deleterious aspects of ageing including loss of growth rate, increasing susceptibility to adverse conditions, and senescence (Fortanier and Jonkers 1976). Shoots from Experiment IV surely had higher physiological age (not known) than those from Experiment V, which were collected 15 months after its induction by apical pruning. The other hypothesis, regarding growth habit of sprouts to explain better survival rates of grafts in Experiment $\mathrm{V}$, needs to be scientifically investigated, once nowadays are only empiric comparisons available about this superiority.

The use of clonal rootstocks has been highlighted in woody fruit and forest species grafting due to superior genetic uniformity (Hartmann et al. 2011). In forest species, several factors have influenced the choice of rootstocks, including similarity of growth and appropriate age (Jayawickrama et al. 1991). However, there are no studies for araucaria clonal rootstocks, for which seedlings are used without any prior selection of mother plants.

The propagation of $A$. angustifolia by grafting has been a challenge to agronomic research (Gurgel and Gurgel-Filho 1967, Kageyama and Ferreira 1975, Nikles 1961, Wendling 2011, 2015, Zanette et al. 2011), generating numerous barriers to clonal forestry of this species. However, the results shown here are novel and promising, bringing new perspectives for application of grafting techniques as propagation methods aiming at early seed production of genetically superior trees.

\section{CONCLUSIONS}

Based on the results obtained in this study we concluded that chip budding with the use of orthotropic sprouts induced from pruned apices of adult trees is the best grafting method for $A$. angustifolia.

\section{ACKNOWLEDGMENTS}

We would like to thank to $\mathrm{CNPq}$ for financing part of the research.

\section{REFERENCES}

Asaah E, Z Tchoundjeu, W Ngahane, A Tsobeng, L Kouodiekong, R Jamnadass, A Simons. 2011. Allanblackia floribunda: a new oil tree crop for Africa: amenability to grafting. New Forests 41(3):389-398. DOI: 10.1007/s11056-010-9230-z.

Carvalho PER. 2003. Espécies arbóreas brasileiras. Brasília, Brazil. Embrapa Informação Tecnológica. 1039 p.

Cordenunsi BR, WE Menezes, MI Genovese, C Colli, AS Gonçalves, FM Lajolo. 2004. Chemical composition and glycemic index of Brazilian pine (Araucaria angustifolia) seeds. Journal of Agricultural and Food Chemistry 52:3412-3416. DOI: 10.1021/jf0348141.

Danner MA, F Zanette, JZ Ribeiro. 2012. Plantation of Brazilian pine for nuts production as a conservation tool. Brazilian Journal of Forestry Research 32:441-451. DOI: 10.4336/2012.pfb.32.72.441.

Dawson TE, LC Bliss. 1993. Plant as mosaics: leaf, ramet, and gender level variation in the physiology of the dwarf willow, Salix arctica. Functional Ecology 7:293-304. DOI: 10.2307/2390208.

Dawson TE, JR Ehleringer. 1993. Gender-specific physiology, carbon isotope discrimination, and habitat distribution in boxelder, Acer negundo. Ecology 74:798-815. DOI: $10.2307 / 1940807$

Dawson TE, JK Ward, JR Ehleringer. 2004. Temporal scaling of physiological responses from gas exchange to tree rings: a gender-specific study of Acer negundo (boxelder) growing under different conditions. Functional Ecology 18:212222. DOI: 10.1111/j.0269-8463.2004.00838.x.

Delucis RA, DA Gatto, DM Stangerlin, R Beltrame, R Trevisan. 
2013. Qualificação da madeira de três espécies de coníferas oriundas de reflorestamentos jovens. Scientia Forestalis 41(100):477-484.

Dias PC, LS Oliveira, A Xavier, I Wendling. 2012. Estaquia e miniestaquia de espécies florestais lenhosas do Brasil. Pesquisa Florestal Brasileira 32(72):453-462. DOI: 10.4336/2012.pfb.32.72.453.

Dias PC, A Xavier, LS Oliveira, GA Félix, IE Pires. 2015. Resgate vegetativo de árvores de Anadenanthera macrocarpa. Revista Cerne 21(1):83-89. DOI:10.1590/0104776020152 1011381.

Fortanier EJ, H Jonkers. 1976. Juvenility and maturity of plants as influenced by their ontogenetical and physiological ageing. Acta Horticulturae 56:37-44.

Gonçalves PM, CPZ Noreña, NP Silveira, A Brandelli. 2014. Characterization of starch nanoparticles obtained from Araucaria angustifolia seeds by acid hydrolysis and ultrasound. Food Science y Technology 58(1):21-27. DOI:10.1016/j. lwt.2014.03.015.

Gurgel JTA, CA Gurgel-Filho. 1967. Métodos de enxertia para o pinheiro brasileiro Araucaria angustifolia (Bertol.) O. Ktze., visando à formação de pomares de sementes. Sivilcultura 6:153-155.

Han Y, Y Wang, J Jiang, W Wang, H Korpelainen, C Li. 2013. Reciprocal grafting separates the roles of the root and shoot in sex-related drought responses in Populus cathayana males and female. Plant, Cell and Environment 36:356-364. DOI: $10.1111 /$ j.1365-3040.2012.02578.x.

Hartmann HT, DE Kester. 2011. Plant propagation: principles and practices. Boston, USA. Prentice Hall. 915 p.

Iszkuło G, AK Jasinska, MJ Giertych, A Boratynski. 2008. Do secondary sexual dimorphism and female intolerance to drought influence the sex ratio and extinction risk of $\mathrm{Ta}$ xus baccata? Plant Ecology 200:229-240. DOI: 10.1007/ s11258-008-9447-5.

Jayawickrama KJS, JB Jett, SE McKeand. 1991. Rootstock effects in grafted conifers: A review. New Forests 5(2): 157173. DOI: $10.1007 / \mathrm{BF} 00029306$.

Kageyama PY, M Ferreira. 1975. Propagação vegetativa por enxertia Araucaria angustifolia (Bert) O. Ktze. Instituto de Pesquisas e Estudos Florestais 12:95-102.

Kuhn SA, JEA Mariath. 2014. Reproductive biology of the "Brazilian pine" (Araucaria angustifolia - Araucariaceae): Development of microspores and microgametophytes. Flora - Morphology, Distribution, Functional Ecology of Plants 209(5-6):290-299. DOI:10.1016/j.flora.2014.02.009.

Lee JM, C Kubota, SJ Tsao, Z Bie, P Hoyos Echevarria, L Morra, M Oda. 2010. Current status of vegetable grafting: Diffusion, grafting techniques, automation. Scientia Horticulturae 127:93-105. DOI: 10.1016/j.scienta.2010.08.003.

Leite GA, V Mendonça, LFM Mendonça, LLGR Dantas, PSCF Cunha. 2013. Portaenxertos e métodos de enxertia na produção de mudas de Atemoieira (Annona squamosa L. x Annona cherimola Mill.). Semina 34(5):2117-2128. DOI: 10.5433/1679-0359.2013v34n5p2117.
Martínez-Ballesta CM, C Alcaraz-López, B Muries, C Mota-Cadenas, M Carjal. 2010. Physiological aspects of rootstockscion interactions. Scientia Horticulturae 127:112-118. DOI: 10.1016/j.scienta.2010.08.002.

Munjunga M, W Kariuki, JBM Njoroge, D Ofori, R Jamnadass. 2014. Effect of rootstock type, scion source and grafting methods on the healing of Allanblackia stuhlmannii grafts under two nursery conditions. African Journal of Horticultural Science. 7:1-10.

Nanami S, H Kawaguchi, T Yamakura. 2005. Sex ratio and gender-dependent neighboring effects in Podocarpus nagi, a dioecious tree. Plant Ecology 177:209-222. DOI: 10.1007/ s11258-005-2210-2.

Nikles DG. 1961. Araucaria cunninghamii "bark-patch" grafting in the field. Australian Forest Research 1(1):45-47.

Ofori DA, T Peprah, S Henneh, JB Von Berg, Z Tchoundjeu, R Jamnadass, AJ Simons. 2008. Utility of grafting in tree domestication with reference to Allanblackia parviflora A. Chev. Ghana Journal of Forestry 23y24:42-48.

Pio R, EA Chagas, W Barbosa, G Signorini, AA Alvarenga, E Abrahão, FA Entelmann. 2008. Métodos de enxertia por garfagem de cultivares de marmeleiro no porta-enxerto 'Japonês'. Revista Brasileira de Fruticultura 30(1):267-270. DOI: 10.1590/S0100-29452008000100050.

Prassinos C, JH Ko, G Lang, AF Iezzoni, KH Han. 2009. Rootstock-induced dwarfing in cherries is caused by differential cessation of terminal meristem growth and is triggered by rootstock-specific gene regulation. Tree Physiology 29:927936. DOI: 10.1093/treephys/tpp027.

Reis JMR, NNJ Chalfun, MA Reis. 2010. Métodos de enxertia e ambientes na produção de mudas de pessegueiro cv. 'Diamante'. Pesquisa Agropecuária Tropical 40(2):200-205. DOI: $10.5216 /$ pat.v40i2.5302

Rozas V, L DeSoto, JM Olano. 2009. Sex-specific, age dependent sensitivity of tree-ring growth to climate in the dioecious tree Juniperus thurifera. New Phytologist 182:687-697. DOI: $10.1111 /$ j.1469-8137.2009.02770.x.

Wendling I. 2011. Enxertia e florescimento precoce de Araucaria angustifolia. Embrapa Florestas (Circular técnica, 272). Consulted 10 jul. 2015. Available in http://ainfo.cnptia.embrapa.br/digital/bitstream/item/41903/1/CT272.pdf.

Wendling I. 2015. Tecnologia de enxertia de Araucaria angustifolia para produção precoce de pinhões. Embrapa Florestas (Comunicado Técnico 351). Consulted 10 jul. 2015. Available in http://ainfo.cnptia.embrapa.br/digital/bitstream/ item/125311/1/CT-351-Ivar.pdf.

Yin H, B Yan, J Sun, P Jia, Z Zhang, X Yan, J Chai, Z Ren, G Zheng, H Liu. 2012. Graft-union development: a delicate process that involves cell-cell communication between scion and stock for local auxin accumulation. Journal of Experimental Botany 63(11):4219-4232. DOI: 10.1093/jxb/ers 109 .

Zanette F, LS Oliveira, LA Biasi. 2011. Grafting of Araucaria angustifolia through the four seasons of the year. Revista Brasileira de Fruticultura 33(4):1364-1370. DOI: 10.1590/ S0100-29452011000400040. 
